\title{
Tinjauan Yuridis Dissenting Opinion terhadap HakimAnggota Atas Perkara Tindak Pidana Penipuan
}

\author{
M. Jordy Dwipayana ${ }^{1}$, Maharani Nurdin' ${ }^{2)}$ \\ ${ }^{1}$ Fakultas Hukum, Universitas Singaperbangsa Karawang. Jl. H.S. Ronggo Waluyo, Telukjambe Timur. \\ ${ }^{2}$ Fakultas Hukum, Universitas Singaperbangsa Karawang. Jl. H.S. Ronggo Waluyo, Telukjambe Timur. \\ Correspondence email: mjdp1999@gmail.com, maharaninurdi@gmail.com
}

\begin{abstract}
Abstrak. Pertemuan hakim yang saling bertentangan dalam menentukan pilihan hukum merupakan perwujudan dari keleluasaan individu pejabat yang ditunjuk untuk menemukan kebenaran materiil. Peluang kehadiran yang definitif bukanlah peluang yang tidak terbatas, melainkan peluang dengan perasaan kewajiban dan kewajiban. Kajian tersebut menggunakan standardisasi regularisasi strategi yuridis untuk studi di mana eksplorasi hukum semacam ini biasanya disinggung sebagai hukum doktrinal atau penelitian kepustakaan. Karena tinjauan ini sepenuhnya bergantung pada pedoman yang disusun, tinjauan ini secara tegas diidentifikasikan dengan perpustakaan karena akan memerlukan informasi tambahan tentang perpustakaan. Hukum acara pidana (KUHAP) 1981 memutuskan bahwa penyelenggaraan pengadilan harus diwakili oleh kesepakatan yang konsisten dari individu-individu dari para ajudikator ketika kesepakatan yang konsisten itu tidak realistis dan keputusannya tergantung pada sebagian besar dengan berfokus pada "yang paling produktif" aturan. Pasal 182 bait (6) KUHAP juga menyebutkan bahwa itu direkam dalam program pribadi kumpul-kumpul. Selain itu, dalam putusan ini hasilnya merupakan penjabaran tertentu antara majelis hakim dalam melihat apakah hal itu dipandang sebagai suatu prosesatau sebagai pelanggaran asas nebis in idem.
\end{abstract}

Kata Kunci: Analisis Hukum, Dissenting Opinion, Hakim

\begin{abstract}
Contradicting judges' gathering in settling on legal choices is the embodiment of the appointed authority's individual flexibility to discover material truth. A definitive opportunity of presence is, not opportunity unbounded, but rather opportunity with a feeling of obligation and obligation. The review USES standardizing regularizing juridical strategies for study in which this kind of lawful exploration is normally alluded to as doctrinal law or library research. Since this review depends entirely on composed guidelines, it is firmly identified with libraries since it would require auxiliary information on the library. The 1981 law on criminal occasions (kuhap) decided that a court administering ought to be represented by a consistent agreement of the individuals from the adjudicators when such consistent agreement was unrealistic and the decision depended on the larger part by focusing on the "most productive" rule. The clarification of 182 stanzas (6) kuhap additionally states that it was recorded in the private program of the get together. Also, in this decision the outcome is a particular translation between the board of judgesin seeing whether it is seen as proceeding or as an infringement of asas nebis in idem.
\end{abstract}

Keywords: Law Analysis, Dissenting Fingerprints, Judge

\section{PENDAHULUAN}

Ketidaksepakatan penilaian majelis hakim dalam menetapkan pilihan pengadilan merupakan inti dari keleluasaan individu hakim dalam mengungkap kebenaran materiil. Kesempatan untuk mengkomunikasikan berbagai perspektif tentang suatu kasus merupakan tanda adanya peluang eksistensial hakim, yang mungkin merupakan jenis kesempatan yang paling tinggi dan mencakup seluruh keberadaan dan karakter hakim yang tidak terbatas pada satu sudut pandang. Peluang eksistensial ini mendorong hakim untuk memahami kehadiran hakim secara inventif dalam memahami perspektifnya secara mandiri, bebas dan tanpa intersesi dalam menemukan kepastian materiil. ${ }^{1}$

Peluang eksistensial pada dasarnya bukanlah peluang yang tidak terbatas, tetapi peluang yang digabungkan dengan perasaan penuh perhatian dan kewajiban. Dalam Undang-Undang Dasar Negara Republik Indonesia Tahun 1945 Pasal 28J ayat (2) memuat asas-asas pokokbahwa:

\begin{abstract}
"Dalam menjalankan hak dan kebebasannya, setiap orang wajib tunduk kepada pembatasan yang ditetapkan dengan undang-undang dengan maksud semata-mata untuk menjaminpengakuan serta penghormatan atas hak dan kebebasan orang lain dan untuk memenuhi tuntutan yang adil sesuai dengan pertimbangan moral, nilai-nilai agama, keamanan, ketertiban umum, dalam suatu masyarakat demokratis. Hal inilah yang menjadi landasan bagi hakim dalam menerapkan kebebasan personalnya sebagai bentuk kesadaran akan tanggung jawab kepada bangsa dan negara dan terutama kepada Tuhan Yang Maha Esa."
\end{abstract}

1 Sri Sutatiek, Menyoal Akuntabilitas Moral Hakim Pidana Dalam Memeriksa, Mengadili dan Memutus Perkara, Yogyakarta: Aswaja Pressindo, 2013, hlm. 17 
Peluang hakim dalam mengungkap kebenaran materiil dalam keadilan pidana Indonesia tidak dapat dipisahkan dari gagasan perangkat hukum umum Eropa daratan yang dianut oleh Indonesia. Aturan mendasar yang terkandung dalam keseluruhan rangkaian undang-undang ini adalah bahwa undang-undang memperoleh kekuatan yang membatasi karena merupakan pedoman sebagai undang-undang yang diatur dan diatur secara efisien. Kebiasaankebiasaan yang sah yang bergantung pada kodifikasi kadang-kadang dapat tetap diputuskan dari penetapan standarstandar yang terdapat di tempat-tempat yang sah bagi perkara-perkara yang diperiksa dalam mengungkap kebenaran materiil sebagai tujuan hukum acara pidana. Dalam pelaksanaan hukum acara pidana, dalam beberapa kasus sumber hukum sebagai hukum seringkali sulit dipahami (slippery term), tidak jelas kepentingannya (hazy term), ambigu dan samar (ambiguity), atau mengandung ketidakjelasan (uncertainty). Terlebih lagi, undang-undang atau sumber sah lainnya yang menjadi alasan pengambilan keputusan dalam menentukan pilihan terkadang bertentangan dengan konstitusi (melanggar hukum) atau dapat menyalahgunakan kebebasan dasar; atau substansinya bertentangan dengan kehadiran pikiran (walaupun penilaiannya baik), dan dalam beberapa kasus pengaturan hukum tidak mengatur masalah yang terjadi secara lokal. ${ }^{2}$

Kekurangan-kekurangan dalam rangkaian undang-undang yang tersusun secara keseluruhan dapat tetap diputuskan dari penetapan standar-standar yang terkandung dalam sumber-sumber yang sah dengan perkara yang sedang diperiksa. Dengan demikian, melalui pedoman hukum, hakim diberi kesempatan untuk melakukan pengungkapan yang sah(rechtsvinding), dalam kondisi dimana undang-undang tidak jelas atau tidak mewajibkan masalah yang terjadi di daerah, dengan pertimbangan bahwa hakim dilarang untuk memberhentikan perkara yang diajukan kepadanya dengan alasan UU tidak mengatur masalah ini.

Hukum dan ketertiban benar-benar menunjukkan bahwa suatu bangsa berpegang teguh pada pelajaran dan standar hukum dan ketertiban di mana hukum dipertahankan sebagai pembantu dan penentu strategi bantalan dalam menyelesaikan standar kehidupan bermasyarakat dan bernegara. ${ }^{3}$ Pasal 1 Ayat (3) Undang-Undang Dasar 1945 berbunyi secara tegasmenyebutkan bahwa: "Negara Indonesia adalah Negara hukum."

Hukum secara keseluruhan adalah segala macam aturan atau aturan dalam kehidupan yang khas, seluruh perilaku yang berlaku dalam kehidupan yang khas, yang dapat dilaksanakan dengan persetujuan. ${ }^{4}$ Ketertiban pada dasarnya menunjuk pada pelaku yang substansial, khususnya pelaku pelanggaran yang benar-benar telah melakukan perbuatan, dan jugaberorientasi pada permintaan terbuka agar tidak mengalah pada perbuatan yang salah, sehingga tidak terjadi pelanggaran. ${ }^{5}$

Fokus hukum cenderung bukan hanya individu yang benar-benar menyerahkan tindakan ilegal tetapi juga kegiatan yang sah yang mungkin terjadi dan perangkat Negara untuk bertindak sesuai dengan undang-undang dan pedoman yang bersangkutan. Seperangkat hukum yang sangat umum adalah jenis persyaratan hukum. Hal ini diharapkan agar hukum dapat membuat kesepakatan dalam kehidupan bermasyarakat, bernegara dan bernegara. ${ }^{6}$

Untuk menjaga keselarasan kehidupan di arena publik, diperlukan berbagai macam aturan sebagai aturan untuk menjaga dan mengarahkan hubungan antara kepentingan individu dan kepentingan populasi secara keseluruhan. Seiring dengan kemajuan di segala bidang, hal itu menyebabkan peningkatan kebutuhan daerah di berbagai bidang sehingga ada juga hukum dan pedoman yang diandalkan untuk dapat menyesuaikan kebutuhan dan kepentingan setiap individu yang unik dan mengejutkan. Apalagi pada akhirnya bisa membuat keamanan dan kerukunan di mata masyarakat. Namun demikian, akhir-akhir ini telah terjadi berbagai perubahan budaya Indonesia yang kemudian dikenal dengan istilah kedaruratan etika. Meningkatnya jumlah pengangguran dan perbuatan salah adalah kesan dari efek perluasan perbuatan salah ini. ${ }^{7}$

Meningkatnya angka pengangguran mempengaruhi tingkat bantuan pemerintah daerah setempat. Kemudian, pada saat itu, dengan tingkat bantuan pemerintah yang rendah, individu- individu tertentu terikat untuk mengabaikan standar atau keputusan hukum yang berlaku. Karenapermintaan besar untuk mengatasi masalah kehidupan dan untuk mengikuti kehidupan, individu- individu tertentu pada akhirnya memutuskan untuk memenuhi kebutuhan mereka dengan cara yang tidak sesuai dengan standar dan aturan hukum materiil. ${ }^{8}$

${ }^{2}$ M. Yahya Harahap, Kekuasaan Mahkamah Agung Pemeriksaan Kasasi dan Peninjauan Kembali Perkara Perdata, Jakarta: Sinar Grafika, 2008, hlm. 91

${ }^{3}$ Darmoko Yuti Witanto dan Arya Putra Negara Kutawaringin, Diskresi Hakim Sebuah Instrumen Menegakkan Keadilan Substantif dalam Perkara - Perkara Pidana, Bandung: Alfabeta, 2013, hlm. 1

${ }^{4}$ Sudikno Mertokusumo, Mengenal Hukum, Yogyakarta: Liberty, 2007, hlm. 40

${ }^{5}$ Ibid., hlm. 12

${ }^{6}$ Ibid., hlm. 13

${ }^{7}$ Ibid., hlm. 14

${ }^{8}$ Soedjono Dirdjosisworo, Hukum Pidana Indonesia dan Gelagat Kriminalitas Masyarakat Pasca Industri, Jakarta: Sinar Grafika, 1991, hlm. 10 
Salah satu jenis perbuatan salah yang saat ini marak di ranah publik adalah pemerasan. Bagi para koruptor, kesalahan penggambaran tidak begitu sulit dilakukan. Pemerasan padadasarnya dapat diselesaikan dengan memiliki kemampuan relasional yang hebat sehingga seseorang dapat membujuk orang lain, baik melalui rangkaian kebohongan atau kata-kata yang dibuat-buat. Dewasa ini, banyak sekali demonstrasi kriminal yang menyesatkan dengan modus yang berbeda-beda. Peningkatan ini menunjukkan bahwa tingkat ilmiah para pelaku misrepresentasi semakin liar. Kesalahan pemerasan adalah pelanggaran terhadap harta benda.

Kejahatan penipuan diatur dalam Buku II KUHP Bab XXV, di mana kesalahan pemerasan dalam struktur utamanya diarahkan dalam Pasal 378 KUHP yang diatur sebagai berikut :

"Barangsiapa dengan maksud untuk menguntungkan diri sendiri atau orang lain secara melawan hukum, dengan memakai nama palsu atau martabat palsu, dengan tipu muslihat, ataupun rangkaian kebohongan, menggerakkan orang lain untuk menyerahkan barang sesuatu kepadanya, atau supaya memberi hutang maupun menghapuskan piutang, diancam karena penipuan dengan penjara paling lama empat tahun."

Dalam pengaturan Pasal 378 KUHP, pemerasan terdiri dari unsur-unsur sasaran yang meliputi barang siapa (seseorang), menggerakkan orang lain dengan tujuan agar orang lain itu (menyerahkan suatu barang, melakukan suatu kewajiban memahami, dan mengeluarkan suatu piutang) dengan memanfaatkan (nama palsu), karakteristik palsu, siasat dan serangkaian ketidakbenaran). Berikutnya adalah komponen emosional yang tergabung dengan tujuan membantu diri sendiri atau orang lain secara tidak sah.

Untuk situasi yang saya alami, lebih spesifiknya situasi pungli dalam Musyawarah Majelis Hakim, ada anggapan yang tidak sepaham mengenai pemahaman aturan hukum Nebis InIdem. Ketua Majelis Hakim dan Anggota Hakim Saya berpendapat bahwa kegiatan berperkara Hasan Basri, S.Sos., Bin Muh. Penggaris adalah proses hukum, sedangkan menurut Hakim Anggota II, Bambang Supriyono, SH. Untuk situasi ini, secara total persyaratan pedoman nebis in idem telah terpenuhi untuk diterapkan.

Sehubungan dengan wacana di atas, maka penulis akan membahas perihal yang pertama yaitu analisis hukum dissenting opinion terhadap hakim anggota atas perkara tindak pidana penipuan berdasarkan Undang-undang Nomor. 8 Tahun 1981 tentang hukum acara pidana,kemudian yang kedua Faktor-faktor yang bisa membuat dissenting opinion perkara penipuan dalam Putusan Nomor 150/Pid.B/2013/PN.BLK.

\section{METODE}

1. Metode Pendekatan

Strategi metodologi yang digunakan dalam penelitian ini adalah regularisasi yuridis dimana teknik eksplorasi legitimasi semacam ini biasa disebut sebagai hukum doktrinal atau penelitian kepustakaan. Disebut penelitian hukum doktrinal karena eksplorasi ini hanya terfokus pada pedoman-pedoman yang tersusun dengan tujuan agar pemeriksaan ini lekat dengan perpustakaan karena akan memerlukan informasi opsional di perpustakaan. ${ }^{9}$

2. Sifat Penelitian

Ide dari pemeriksaan ini adalah investigasi grafis karena eksplorasi ini diharapkan dapat memberikan informasi yang cukup akurat tentang masalah yang diteliti dan membedah informasi yang didapat untuk menjawab masalah tersebut. ${ }^{10}$

3. Sumber Data

Tinjauan ini menggambarkan atau menggambarkan informasi yang diperoleh secara normatif dan kemudian digambarkan untuk menggambarkan informasi yang dikumpulkan secara metodis. Informasi yang digunakan sebagai sumber informasi utama adalah sumber informasi tambahan, yaitu informasi spesifik yang diperoleh melalui studi kepustakaan yang terdiri dari bahan legitimasi esensial dan opsional yang meliputi :

a. Materi sah yang esensial adalah materi sah yang membatasi dan terdiri dari standarisasi aturan yang mengidentifikasi dengan masalah hukum yang ada. Bahan-bahan penting yang sah yang digunakan dicatat sebagai hard copy proposal ini adalah :

1) Undang-Undang Dasar Negara Republik Indonesia Tahun 1945.

2) Kitab Undang-undang Hukum Pidana.

3) Putusan Pengadilan Negeri Nomor: 150/Pid.B/2013/PN.BLK.

b. Bahan Hukum Tambahan adalah bahan sah yang memberikan klarifikasi dari bahan hukumpenting seperti buku, buku harian/kertas logika dan situs web.

c. Bahan Hukum Tersier adalah bahan hukum yang memberikan petunjuk atau penjelasan tentang bahan hukum

\footnotetext{
${ }^{9}$ Abdulkadir Muhammad, Hukum dan Penelitian Hukum, PT.Citra Aditya Bakti, Bandung, 2004. hlm. 67

${ }^{10}$ Ibid., hlm. 127
} 
yang esensial dan bahan tambahan yang sah seperti referensi kata halal dan referensi kata bahasa Indonesia yang sangat besar.

4. Teknik Pengumpulan Data

Tata cara pemilihan informasi dilakukan melalui penelitian kepustakaan, untuk lebih spesifiknya eksplorasi dilakukan dengan menganalisis bahan pustaka secara pasti disebut informasi tambahan. Informasi tambahan yang digunakan dalam penyusunan eksplorasi ini diperoleh dari buku-buku eksklusif atau diperoleh dari perpustakaan, buku harian/logika yang didapat dari web-site dan pedoman-pedoman hukum, dan untuk mendapatkan informasi pendukung dilakukan pertemuan-pertemuan dan pengamatan lapangan (Field Research). ${ }^{11}$

5. Teknik Analisis Data

Pemeriksaan informasi yang dilakukan dalam penelitian teori ini menggunakan informasi subjektif. Pemeriksaan informasi subjektif menyiratkan penggambaran informasi berkualitas sebagai kalimat yang biasa, masuk akal secara konsisten, tidak menutupi dan berhasil untuk bekerja dengan terjemahan informasi dan pemahaman tentang konsekuensi penyelidikan. Teknik investigasi informasi subjektif ini digunakan agar penulis dapat membidik tambahan pada pemahaman dan pengkajian bahan-bahan hukum dan hukum yang sesuai dengan pokok yang menjadi judul penulisan karya ini.

\section{HASIL DAN PEMBAHASAN}

Tinjauan Yuridis dissenting opinion terhadap hakim anggota atas perkara tindak pidana penipuan berdasarkan Undang-undang Nomor 8 Tahun 1981 perihal hukum acara pidana

Perkara Posisi saat ini Bahwa Termohon Hasan Basri, S.Sos., Bin Muh. Raja pada bulan Maret 2009 hingga April 2009 atau jika tidak pada waktu tertentu pada tahun 2009 di Jln. Abd. Aziz Kel. Tanah Kongkong Kec. Ujungbulu Kab. Bulukumba atau mungkin di tempat-tempat tertentu yang masih dikenang sebagai lokasi Pengadilan Negeri Bulukumba, "dengan harapan menolong diri sendiri atau orang lain secara melawan hukum dengan menggunakan nama palsu atau kebanggaan palsu dengan bermuka dua atau rangkaian penyesatan menggerakkan orang lain untuk memberikan up produk sesuatu kepadanya atau untuk memberikan kewajiban atau diskon kewajiban dikompromikan dalam pemerasan yang tindakan responden diajukan dengan cara-cara sebagai berikut:

Pada titik dan tempat sebagaimana tersebut di atas, bermula ketika saksi korban Jumase Bin H.Caring bersama dua kerabat dan satu keponakan, Sudirman Bin H.Caring, Sumrah Binti

H. Sadar dan Saenal Bin Basri ditawari lamaran oleh penggugat HASAN BASRI, S.Sos. , Bin MUH. Penguasa untuk meloloskan CPNS tanpa melalui suatu pilihan tergantung pada prasyarat bahwa pemerhati korban (pendamping) harus merencanakan uang tunai masing-masing dalam takaran Rp. 40.000.000,- (empat puluh juta rupiah) dimana uang tersebut akan digunakan untuk administrasi menjadi pegawai negeri, dimana sistemnya, angsuran pokoknya sebesar Rp. 5.000.000,- (5.000.000 rupiah) sebagai biaya persiapan pokok, setelah SK CPNS diperoleh oleh Saksi (pendamping) korban maka pada saat itulah kelebihan angsuran dapat dilakukan. Penggugat HASAN BASRI, S.Sos., Bin MUH. Penggaris mengatakan, jika pengamat korban (pendamping) tertarik, cukup mendatangi tempat Saksi H. Harmin, S. Wadah Sanre. Pada tanggal 10 Maret 2009, pengamat korban dan kedua saudaranya mendatangi tempat Saksi H. Harmin, S. Wadah Sanre untuk menyerahkan Rp. (5.000.000 rupiah) sebagai underlying game plan untuk CPNS. Kemudian pada saat itu, pada tanggal 27 Maret 2009, pemerhati korban (pendamping) kembali dimintakan uang oleh penggugat HASAN BASRI, S.Sos., Bin MUH SULTAN sebesar Rp. 10.000.000,- (sepuluh juta rupiah). Pada tanggal 31 Maret 2009, Termohon HASAN BASRI, S.Sos., Bin MUH SULTAN meminta Rp. 10.000.000,(sepuluh jutarupiah) kepada saksi korban (pendamping) sehingga takaran uang tunai yang dikumpulkan oleh setiap orang adalah Rp. 25.000.000,- (25 juta rupiah). Kemudian, pada saat itu, pada tanggal 18 April 2009, saksi H. Harmin, S. Canister Sanre mendatangi rumah korban dan menjelaskan bahwa kelebihan uang tersebut harus dibayarkan mengingat sekitar saat itu yang berperkara adalah HASAN BASRI, S. .Sos., Bin MUH. King berada di Jakarta sebelumnya mengadakan SK CPNS yang bertempat dengan pengamat korban (pendamping), maka pada tanggal 19 April 2009 pengamat korban mendatangi tempat saksi H. Harmin, S. Canister Sanre untuk menyerahkan Rp. 45.000.000,- (45 juta rupiah) yang merupakan uang tunai atas ketidakhadiran pengamat yang bersangkutan dan kedua kerabatnya. Dimana setiap kali saksi korban (pendamping) berperkara HASAN BASRI, S.Sos., Bin MUH. Penggaris. Setelah penundaan yang cukup lama, pemerhati korban (pendamping) tidak mendapatkan perintah CPNS yang dijamin oleh penggugat HASAN BASRI, S.Sos., Bin MUH. Raja, kemudian, pada saat itu, pada 26 Juli 2012, pengamat korban (pendamping) sepakat dengan tergugat HASAN BASRI, S.Sos., Bin MUH. Raja yang substansinya adalah Termohon HASAN BASRI, S.Sos., Bin MUH. Sultan memiliki opsi untuk mengembalikan uang tunai yang bertempat dengan saksi korban (pendamping) pada hari Senin, 03 September 2012, namun hingga saat ini uang tunai yang berada di tempat dengan saksi korban (pendamping) tersebut belum juga dikembalikan oleh pihak korban. berperkara HASAN BASRI, S.Sos., Bin MUH. Sultan dan pemerhati korban serta kedua kerabatnya mengalami

${ }^{11}$ Ibid., hlm. 53-56 
musibah materil sebesar Rp. 120.000 .000 (seratus dua puluh juta rupiah), sedangkan keponakan pemerhati korban, Saenal Bin Basri, mengalami kekurangan sebesar Rp. 25.000.000,- (25 juta rupiah) yang ditunjukkan dengan bukti tertulis yang dilampirkan pada catatan. Jadi kerugian lengkap saksi korban (pendamping) adalah Rp. 145.000.000,(seratus 45 juta rupiah). Kegiatan Terdakwa tersebut sebagaimana diatur dan tunduk pada perbuatan pidana dalam Pasal 378KUHP.

Bahwa berdasarkan kenyataan yang terungkap di awal seperti yang tergambar dalam percakapan komponen 1 dan 2, yang menurut Majelis Hakim tidak dapat dipisahkan dan membentuk suatu kesatuan tersendiri dengan komponen ini, terbukti bahwa karena perkataan (rangkaian) kepalsuan telah dibuktikan dalam pembuktian komponen selanjutnya yang dirujuk di atas, sehingga menggerakkan saksi korban Jumase Bin H.Caring, saksi Sudirman Bin H.Caring, saksi Sumrah Binti H. Sadar dan saksi Saenal Bin Basri berbicara kepada Basri Bin H. Zainuddin untuk menyerahkan sejumlah uang kepada pihak berperkara dalam beberapa tahap dengan jumlah keseluruhan Rp. 160.000.000 (seratus enam puluh juta rupiah).

Pemeriksaan terhadap kasus tersebut di atas adalah bahwa pengesahan hukum merupakan upaya untuk mewujudkan pemikiran tentang kesetaraan, kepastian hukum dan keuntungan sosial ke dalam dunia nyata. Jadi pengesahan hukum pada dasarnya adalah rangkaian pemikiran. Otorisasi hukum adalah metode yang terlibat dengan mengajukan upaya untuk menegakkan atau benar-benar bekerja standar hukum sebagai pembantu untuk penghibur dalam kemacetan jam sibuk atau koneksi yang sah dalam kehidupan persahabatan dan negara. Implementasi hukum adalah suatu karya untuk memahami pemikiran dan gagasan hukum yang diandalkan oleh individu untuk menjadi kenyataan. Implementasi hukum merupakan suatu siklus yang mencakup banyak hal. Menurut Satjipto Rahardjo, pelaksanaan hukum pada dasarnya adalah pengesahan pikiran atau gagasan tentang pemerataan, kebenaran, kemanfaatan sosial, dan lain-lain. Jadi syarat hukum adalah upaya mewujudkan pemikiran dan gagasan tersebut.

Pada dasarnya pelaksanaan hukum mencirikan sifat-sifat atau putusan-putusan yang mengandung keadilan dan kebenaran, pengesahan hukum bukan hanya tugas dari ahli hukum yang dikenal secara tradisional, tetapi merupakan kewajiban setiap orang. Padahal, sebanding dengan hukum publik, otoritas publiklah yang mampu.

Implementasi hukum dipisahkan menjadi dua, lebih spesifiknya:

1. Ditinjau dari sudut subjekya:

Dari perspektif luas, ukuran persyaratan hukum mencakup semua subjek yang sah dalam setiap hubungan yang sah. Setiap orang yang melakukan pengaturan aturan atau menyelesaikan sesuatu atau tidak mencapai sesuatu tergantung pada standar hukum yang relevan, menyiratkan bahwa dia melakukan atau menegakkan hukum dan ketertiban.

Dari sudut pandang tipis, kewenangan hukum hanya dicirikan sebagai upaya otoritas pelaksana hukum tertentu untuk memastikan dan menjamin bahwa hukum danketertiban berjalan sebagaimana mestinya.

2. Ditinjau dari sudut objeknya, yaitu dari segi hukumnya:

Dari perspektif ekspansif, otorisasi undang-undang yang menggabungkan sisi positif dari kesetaraan yang berisi suara standar formal dan sisi positif dari kesetaraan yang ada di arena publik. Dari perspektif yang ketat, persyaratan hukum hanya menyangkut pelaksanaan pedomanformal dan tersusun.

Joseph Goldstein membedakan penerapan hukum pidana menjadi 3 bagian, yaitu:

a. Persyaratan total, khususnya sejauh mana otorisasi hukum pidana seperti yang didefinisikan oleh hukum kesalahan yang cukup besar. Persyaratan lengkap hukum pidana adalah tidak masuk akal mengingat fakta bahwa ahli hukum sepenuhnya dibatasi oleh hukum teknik pidana, yang mencakup standar penangkapan, penahanan, penggeledahan, penyitaan, dan penilaian pemula. Lebih dari itu, dapat dibayangkan bahwa hukum pidana yang bermakna itu sendiri memberikan batasan-batasan. Misalnya, diperlukan suatu pengaduan terlebih dahulu sebagai syarat dakwaan delik keberatan (klacht delicten). Gelar terbatas ini disinggung sebagai ruang tanpa otorisasi.

b. Persyaratan penuh, setelah luasnya kewenangan hukum pidana dikurangi dengan ruang tidak adanya implementasi dalam persyaratan hukum, persyaratan hukum diandalkan untuk meningkatkan persyaratan hukum.

c. Persyaratan aktual, menurut Joseph Goldstein, otorisasi penuh dianggap bukan asumsi yang masuk akal, dengan alasan bahwa ada batasan seperti waktu, staf, instrumen analitis, cadangan, dll, yang semuanya memerlukan kehati-hatian dan sisanya adalah hal yang disebut penerapan asli.

Penilaian yang bertentangan merupakan landasan yang melegitimasi pembedaan penilaian hakim (minoritas) atas pilihan pengadilan. Penilaian yang bertentangan adalah penilaian terhadap sekurang-kurangnya seorang hakim dalam mengatakan sesuatu yang menunjukkan ketidakpuasannya terhadap pilihan sebagian besar hakim dalam majelis hakim yang memutuskan pilihan dalam sidang pengadilan, penilaian ini akan dikenang untuk pilihannya, namun demikian pendapat yang tidak setuju sentimen) tidak akan memulai tren yang membatasi atau menjadi bagian dari 
penilaian.

Penilaian yang bertentangan itu sendiri dimulai dan semakin sering digunakan di negara- negara yang berpegang pada keseluruhan rangkaian hukum Anglo Saxon seperti Amerika Serikatdan Inggris. Dalam keseluruhan undang-undang ini, penilaian yang bertentangan digunakan dalam hal ada perbedaan penilaian antara otoritas yang ditunjuk dan hakim lain yang pilihannya lebih besar. Perspektif juri yang tidak sama dengan pilihan juga akan dikaitkan dengan pilihan dan menjadi penilaian yang kontradiktif.

Sejak lahirnya Undang-Undang Nomor 4 Tahun 2004 tentang Kekuasaan Kehakiman, telah terjadi pertunjukkan di antara individu-individu dari suatu majelis hakim dimana apabila dalam rapat musyawarah majelis hakim tidak tercapai kesepakatan, penilaian minoritas memutuskan yang berbeda-beda. dari efek samping dari pertemuan pertimbangan para hakim harus diingat untuk bagian pilihan dan struktur pilihan. yang merupakan bagian yang diperlukan dari pilihan.

Undang-undang Nomor 8 Tahun 1981 perihal Kitab Undang-Undang Hukum AcaraPidana (KUHAP) mengatur bahwa suatu pilihan pengadilan harus didasarkan pada kesepahaman yang konsisten oleh individu-individu dari majelis hakim. umumnya menguntungkan responden. Klarifikasi Pasal 182 ayat (6) KUHAP juga menegaskan bahwa hal itu dicatat dalam risalah rapatkumpul yang bersifat tertutup. Selanjutnya, bila mengacu pada pengaturan KUHAP, maka perbedaan penilaian (langsung) antara individu dari majelis hakim dipandang sebagai suatu hal yang tidak dapat disentuh dan berada di luar imajinasi, sehingga otonomi hakim dalam hal pelaksanaan hukum acara pidana di Indonesia belum sepenuhnya tuntas.

Demikian, dalam melihat kasus-kasus demonstrasi kriminal yang menyesatkan, jika kita menghubungkannya dengan hipotesis pengesahan undang-undang seperti yang ditunjukkan oleh pasalnya, khususnya sejauh undangundang. Dari perspektif yang luas, persyaratan hukum yang menggabungkan kualitas kesetaraan yang berisi suara prinsip-prinsip formal dan kualitas kesetaraan yang ada di arena publik. Kita dapat melihat bahwa di sini para pelaksana hukum melakukan persyaratan hukum sesuai dengan pedoman formal, untuk situasi ini KUHAP.

Kemudian, pada titik itu, ditegaskan oleh pandangan Joseph Goldstein yang mengakui pengesahan hukum menjadi 3 bagian, salah satunya adalah pelaksanaan yang lengkap, untuk lebih spesifik sejauh mana persyaratan hukum pidana seperti yang direncanakan oleh hukum yang berarti perbuatan salah. Implementasi hukum pidana secara tuntas tidak terbayangkankarena para ahli hukum sepenuhnya dibatasi oleh hukum acara pidana, yang jika kita kaitkan dengan kasus-kasus penyesatan, Putusan Nomor: 150/Pid.B/2013/PN.BLK. maka pada saat itu pertimbangan penilaian tidak setuju terhadap keadaan tersebut bertentangan dengan Pasal 182 ayat 7 Undang-Undang Nomor 8 Tahun 1981, dengan alasan bahwa dalam KUHAP berbagai penilaian tersebut bersifat rahasia dan harus dicatat saja. dalam pengaturan pilihan pengadilan. Pedoman Undang-undang Nomor 8 Tahun 1981 tentang hukum acara pidana.

Situasi penilaian yang kontradiktif adalah sebagai undang-undang untuk kasus-kasus perbandingan yang menjadi pertanyaan perbedaan penilaian, namun tidak dapat digunakan sebagai premis hukum hanya sebagai semacam perspektif, karena mengamati aturan umumhukum umum yang adil. Memahami hukum yang sistematis. ${ }^{12}$

\section{Faktor-faktor yang bisa membuat dissenting opinion perkara penipuan dalam Putusan Nomor 150/Pid.B/2013/PN.BLK}

Disampaikan oleh M. Natsir Asnawi, majelis hakim pada intinya akan melengkapi dua hal dalam pertimbangan majelis, yaitu:

1. Cari tahu pihak mana yang menang dalam demonstrasi dan pertemuan mana yanglalai untuk berdemonstrasi. Setiap hakim bagian akan memberikan pandangannya terhadap faktor-faktor nyata yang terungkap di pendahuluan. Setiap hakim akan memantapkan realitas saat ini sebagai pendekatan untuk menetapkan hukumnya.

2. Membangun hak-hak yang sah dan hubungan antara pertemuan-pertemuan. Setelah otoritas yang ditunjuk membangun realitas saat ini, hakim kemudian, pada saat itu, mengusulkan tujuan yang dapat dilakukan dengan mencari tahu siapa yang memenuhisyarat untuk apa serta mengatur hubungan yang sah antara pertemuan.

Jimly Ash-Shiddieqy berpendapat bahwa keputusasaan penilaian tidak setuju hanya dalam pilihan yang mengakui klaim / aplikasi. Jika itu diberhentikan atau di (NO), tidak buruk untuk menumpuk tidak setuju. Penilaian ini harus dimaknai dalam membicarakan pilihan MK (yang konklusif dan membatasi/tidak ada lagi pengobatan yang halal). Jadi sebenarnya kasus yang dia curigai. Ini berbeda ketika diterapkan pada pengadilan contoh pertama dan permintaan dengan alasan bahwa masih ada obat yang sah terhadap mereka. Jimly Ash-shiddiqy juga menerima bahwa semua otoritas yang ditunjuk untuk situasi di dewan dapat melakukan penilaianyang bertentangan.

Bagaimanapun juga, suatu pilihan merupakan akibat dari renungan dan ijtihad ajudikator terhadap pandangannya terhadap kasus a quo tanpa hambatan, lugas dan sungguh-sungguhmenggunakan pertimbangan yang halal. Ada beberapa faktor yang mempengaruhi keputusan dalam memutuskan:

${ }^{12}$ Ibid., hlm. 70 
1. Informasi kasar, khususnya faktor-faktor yang terkait dengan kebangsaan, agama,pelatihan kasual, dll.

2. Informasi instrumental, faktor yang diidentifikasi dengan pekerjaan dan instruksiformal.

3. Faktor alam, ekologi, sosial-sosial yang mempengaruhi keberadaan otoritas yangditunjuk, misalnya iklim otoritas, dll. ${ }^{13}$

Apabila dilihat lebih jauh, faktor-faktor tersebut dibagi atas faktor subjektif dan faktor objektif yaitu:

1. Faktor subjektif yaitu:

a. Perilaku yang disimpulkan, disposisi hakim tergantung pada penggugat yang diperiksa dan diadili adalah individu yang tidak diragukan lagi tercela dan harus ditolak.

b. Disposisikan perilaku yang penuh gairah. Seorang hakim yang dengan mudah marah tidak akan sama dengan gagasan seorang pejabat yang ditunjuk yang tidak benar-benar terganggu. Keputusan dari otoritas yang ditunjuk yang dengan mudahmarah dan dendam akan unik dalam kaitannya dengan hakim pasien.

c. Disposisi kekuatan praduga, mentalitas lain yang mempengaruhi pilihan adalah keangkuhan kekuatan. Di sini penguasa yang ditunjuk merasa dirinya luar biasa dan cemerlang, melebihi individu lainnya (Jaksa, Pembela, apalagi Terdakwa).

d. Pelajaran dari seorang hakim juga menarik, karena dilihat dari semua hal, karakter pejabat yang ditunjuk itu tercakup dalam perilaku yang bergantung pada etika hakim itu sendiri, terutama dalam memeriksa dan memilih suatu perkara.

2. Faktor objektif yaitu:

a. Landasan sosial, budaya, agama, pelatihan otoritas yang ditunjuk pasti akan mempengaruhi pilihan seorang hakim. Meskipun tidak langsung, tetapi pada dasarnya berdampak pada hakim dalam menentukan pilihan.

b. Keterampilan yang ditunjukkan, wawasan, dan metodologi yang dipoles dari otoritas yang ditunjuk memengaruhi pilihannya. ${ }^{14}$

Kemudian pada pilihan nomor: 150/Pid.B/2013/PN.BLK tersebut ada beberapa faktor yang menurut saya dapat membuat penilaian yang kontradiktif antara lain:

1. Dalam Eksepsi:

Menimbang, bahwa terhadap tanggapan termohon yang berkaitan dengan penjelasan di balik pelanggaran Pasal 74 KUHP tentang delik gerutuan dan sedapat mungkin untuk protes, bahwa pihak Kepolisian mendapat aduan setelah melampaui tenggang waktu yang diperlukan Pasal 74 ayat (1) dan ayat (2) dan Pelanggaran Pasal76 KUHP tentang larangan mendokumentasikan suatu perkara untuk kedua kalinya dalam suatu demonstrasi/perkara yang telah dipilih oleh pengadilan dengan kewenangan super. kekuasaan legitimasi yang tahan lama, untuk penjelasan yang sama, subjek dan objek yang sama dan pengadilan yang serupa (Nebis In Idem), ini juga diatur dalam Pasal 18 ayat (5) Undang-Undang N0.39 Tahun 1999 tentang Hak Asasi Manusia (HAM), karena diidentikkan dengan mendemonstrasikan topik penting kasus, seperti yang diungkapkan dalam pilihan sementara, kemudian, pada saat itu, alasan-alasan ini akan dipertimbangkan dalam mendemonstrasikan topikkasus.

2. Dalam Pokok Perkara

Menimbang, meskipun untuk keadaan ini termohon dibawa oleh Jaksa Penuntut Umum ke persidangan dengan dakwaan yang diatur sebaliknya, Majelis Hakim dalam mempertimbangkan penuntutan setelah melihat kenyataan yang terungkap di persidangan dapat langsung memilih dakwaan mana yang dapat dibuktikan oleh Penuntut Umum.

Menimbang bahwa Jaksa Penuntut Umum dalam dakwaan pidananya berpendapat bahwa perbuatan termohon telah memenuhi unsur Pasal 378 KUHP sebagaimana yang didakwakan dalam Dakwaan Alternatif Pertama.

Menimbang, meskipun setelah mempertimbangkan kenyataan-kenyataan yang ada dan bukti-bukti yang terungkap di awal, Majelis Hakim menilai bahwa penuntutan yang tepat untuk diterapkan dalam situasi ini adalah dakwaan elektif utama, dengan pertimbangan seperti yang akan digambarkan lebih lanjut dalam penggambaran. komponen pasal-pasal yang didakwakan dalam dakwaan pemilihan pendahuluan. NS.

Menimbang, meskipun di samping itu, Majelis Hakim akan mempertimbangkan apakah kegiatan Terdakwa mengandung komponen-komponen sebagaimana dimaksud dalam penuntutan elektif utama, khususnya penyalahgunaan Pasal 378 KUHP yang komponen-komponennya sebagai berikut:

Setiap individu dengan tujuan untuk membantu dirinya sendiri atau orang lain secara tidak sah dengan menggunakan nama palsu atau kebanggaan palsu melalui transaksi ganda atau perkembangan kebohongan; Memotivasi orang lain untuk menyerahkan sesuatu kepadanya atau memberikan kewajiban atau mendiskontokan

\footnotetext{
${ }^{13}$ Ibid.

${ }^{14}$ Ibid.
} 
piutang.

Untuk lebih jelasnya, Majelis Hakim akan menggambarkan komponen- komponen tersebut sebagai berikut, seperti halnya mempertimbangkan semua hal yang berkaitan dengan penjelasan atau segala sesuatu yang terkandung dalam pemberitahuan perlindungan Terdakwa:

Ad. 1. Barang siapa memperhatikan bahwa yang dimaksud dengan komponen barang siapa dalam KUHP adalah setiap orang atau unsur sah yang melakukan demonstrasi dan kepada siapa dapat dimintakan pertanggungjawaban. Untuk situasi ini, sebelum pendahuluan, penggugat bernama Hasan Basri diperkenalkan. S.Sos Bin Muhammad Sultan yang sifatnya keseluruhan tertuang dalam dokumen permulaan perkara dan berita acara penilaian oleh agen, yang selama pendahuluan dapat tersedia, dapat mengikuti dan mengikuti prosedur pendahuluan dan dapat memberikan reaksi terhadap keterangan para saksi, seperti memberikan jawaban atas pertanyaan Hakim dengan baik dan mudah sehingga tidak ada hal-hal yang dapat dipikirkan untuk membatalkan kesalahan tersebut (dikecualikan dari Pasal 44 KUHP).

Mempertimbangkan bahwa, bagaimanapun, untuk memutuskan apakah yang dipersalahkan adalah subjek demonstrasi kriminal untuk situasi ini, masih penting untuk menunjukkan apakah termohon benar-benar telah melakukan tindak lanjutseperti yang dituduhkan. Dalam hal fakta-fakta benar-benar menegaskan bahwa penggugat melakukan suatu rangkaian kegiatan yang memuaskan setiap salah satu komponen pasal hukum pidana yang dipersalahkannya, maka pada saat itu komponen "barang siapa" telah puas bahwa responden adalah pelaku dari demonstrasi kriminal untuk situasi ini.

Menimbang, bahwa untuk itu Majelis akan melihat apakah komponen- komponen yang menyertainya telah dipenuhi oleh kegiatan para terdakwa:

Ad. 2. Dengan tujuan untuk secara melawan hukum membantu diri sendiri atau orang lain dengan menggunakan nama palsu atau kebanggaan palsu dengan penyesatan atau perkembangan kebohongan;

Mengingat komponen-komponen pasal yang dituding di atas mengandung komponen-komponen yang bersifat pilihan, maka Majelis Hakim akan mempertimbangkan salah satu komponen dari komponen yang dapat dibuktikan sebelum pemeriksaan pendahuluan.

Menimbang, bahwa dalam pengawasan Majelis Hakim menunjukkan apakah kegiatan Terdakwa telah memenuhi komponen-komponen di atas sebagaimana digambarkan dalam hukum positif. Pertama-tama, Majelis akan menggambarkan Definisi "dengan tujuan" dalam komponen selanjutnya ini. Kata-kata dengan tujuan di sini tidak dapat dipisahkan dari pentingnya OPZET di mana pada komponen kedua telah ditetapkan secara resmi dan setiap kali dilihat dari rangkaian pengalaman, itu adalah interpretasi dari kata-kata MET HET OOGMERK jadi OPZET dalam komponen berikutnya ini. harus diuraikan sebagai bayaran sebagai Opzet als oogmerk sehingga makna dari pelakunya tidak boleh diartikan secara kontras selain dengan tujuan membantu dirinya sendiri atau orang lain secara ilegal, sebagai komponen sadar, pelaku mengakui/membutuhkan manfaat untuk dirinya sendiri/orang lain, ia juga menyadari bahwa dia tidak memenuhi syarat untuk manfaat seperti itu. Bahwa yang dimaksud dengan kesengajaan menurut ingatan ilustratif (Memorie van Toelichting) adalah: "menginginkan dan memahami" peristiwa suatu kegiatan dan hasil-hasilnya mengandung pengertian bahwa seseorang yang mengajukan suatu kegiatan dengan sengaja harus memaknai dan memahami kegiatan tersebut serta fungsinya. hasil, dengan demikian harapan terfokus pada suatu kegiatan. Berkenaan dengan yang dimaknai: "Nama palsu adalah nama yang bukan semata-mata nama pelakunya, sedangkan keadaan palsu menyatakan bahwa ia berada dalam keadaan yang tidak benar yang membuat korban percaya kepadanya. Selanjutnya dengan alasan menerima, maka pada saat itu korban memberikan barang atau membuat kewajiban atau mengurangi kewajiban; Dikatakan dengan akal dan penyesatan adalah suatu demonstrasi yang bukan kata-kata yang menyesatkan, sehingga seseorang dengan penalaran yang khas dapat tertipu olehnya.Mengenai pentingnya wacana palsu, adalah sebagai beberapa kata yang salah yang didalangi sedemikian rupa seolah-olah mereka benar.

Mempertimbangkan bahwa jika pengaturan ini diidentikkan dengan kenyataan yang terungkap sebelum pemeriksaan pendahuluan, keterangan para pengamat, sama seperti pembuktian yang dikuatkan oleh keterangan Terdakwa. Terungkap bahwa memang benar pada Maret 2009, saksi Sudirman Bin H.Caring dansaksi H. Harmin, S. Wadah Sanre mengetahui tentang pengakuan Calon Pegawai Negeri Sipil (CPNS) tanpa pilihan atau tanpa ujian tergantung pemberitahuan. dari Terdakwa yang datang untuk meninjau rumah H. Harmin, S. Canister Sanre di Jalan ABD Azis, Desa Tanah Kongkong, Kecamatan Ujung Bulu, Kabupaten Bulukumba, yang selanjutnya dibedakan korban yaitu Jumase Bin H. Sadar, saksi Sumrah Binti H. Sadar dan Basri Bin H. Zainuddin, kemudian di Mengingat kepercayaan kepadaTerdakwa, para pengamat, termasuk pengamat Saenal Bin Basri yang berbicara kepada Basri Bin H. Zainuddin, kemudian pada saat itu memberikan sejumlah uang kepada penggugat dalam beberapa tahap. Sedangkan uang tunai yang didapat dari pengamat dikirimkan oleh Tergugat ke salah satu pihak di Jakarta, yaitu I Nyoman Arse, SH., MH., yang mengaku sebagai Direktur Pengadaan Calon Pegawai Negeri Sipil 
pada Aparatur Sipil Negara Jakarta Pusat. Agency, melalui nomor rekor demi Winarti, Bambang. SR dan Sulastri, meskipun Tergugat sudah tidak pernah mengenalI Nyoman Ass atau Winarti, Bambang. SR dan Sulastri. Bahwa selama ini terjadi begitu saja, saksi korban Jumase Bin H. Sadar, saksi Sudirman Bin H. Sadar, saksi Sumrah Binti H. Sadar dan Basri Bin H Zainuddin tidak menjadi Pegawai Negeri Sipil atau CPNS sebagaimana dijamin Terdakwa dan Terdakwa tidak pernah mengembalikan uang tunai pengamat, meskipun fakta bahwa mereka barubaru ini bersumpah untuk mengembalikannya.

Menimbang, bahwa berdasarkan kenyataan-kenyataan yang sah tersebut, menurut Majelis Hakim, Terdakwa telah memberikan rangkaian kata-kata khususnya penggambaran kepada saksi korban Jumase Bin H. Sadar, saksi Sudirman Bin H. Sadar, saksi Sumrah Binti H. Sadar dan Basri Bin H Zainuddin bahwa Pemohon memiliki opsi untuk meloloskan pengamat untuk menjadi pegawai negeri atau CPNS hanya dengan membayar sejumlah uang tertentu.

Mengingat demikian, Majelis Hakim diarahkan oleh atau berdasarkan Undang-Undang Republik Indonesia Nomor 18 Tahun 1961 tentang pokok-pokok urusan, khususnya yang termuat dalam Bab II. Tentang pengakuan, pengaturan dan pelepasan perwakilan. Jadi telah dinyatakan dengan jelas bahwa dalam pendaftaran atau kemungkinan perolehan pegawai pemerintah, ada interaksi pilihan yang parah dan tidak semata-mata didasarkan pada akomodasi sejumlah uang. Sebagai tambahan telah ditegaskan oleh saksi TAUFIK RAMLI, S.STP., MM BIN H. RAMLI selaku Kepala Sub Bidang Pengadaan Pegawai Negeri Sipil pada Kantor Badan Kepegawaian Daerah (BKD) Kab. Bulukumba.

Menimbang, meskipun melihat hal tersebut, Majelis Hakim menilai Terdakwa hanya memberikan gambaran-gambaran palsu dan bermasalah yang membuat orang lain (untuk situasi ini saksi korban dan pengamat berbeda) mengakui kenyataan. Terlepas dari kenyataan bahwa gambar-gambar ini belum terbukti valid (hanya perkembangan kepalsuan). Hal ini juga sesuai dengan HR 8 Maret 1926, yang menyatakan: "Ada perkembangan kebohongan, jika di antara kebohongan yang berbeda ada hubungan sedemikian rupa dan satu kebohongan melengkapi kebohongan yang berbeda dengan tujuan agar mereka sama-sama menghasilkan suatu kebohongan. gambar palsu seolah-olah itu jelas salah. kenyataan."

Bahwa perbuatan para penggugat menurut Majelis Hakim dilakukan secara melawan hukum atau secara wederrechtelijk yang ditunjukkan oleh Simons (Lihat buku KUHP Satochid Kartanegara, Kumpulan Ceramah Bagian Kesatu) menjelaskan bahwa tidak sah adalah "demonstrasi yang menentang hukum sebagai suatu peraturan, baik yang tersusun maupun yang tidak tertulis". Pada hakekatnya Van Hammel, TJ Noyon dan Hoge Raad mengandung arti bertentangan dengan hak-hak individu orang lain atau perbuatan tanpa hak dan wewenang, mengingat Tergugat dalam penegasannya sendiri menyatakan bahwa sebagai salah satu sub bidang Dinas Pertanian, Terdakwa tidak mempunyai kewajiban atau wewenang yang diidentikkan dengan pengakuan CPNS, namun seolah - olah Tergugat diyakinkan akan kenyataan meskipun Terdakwa tidak pernah mengetahui atau melakukan cross check terhadap kenyataan tersebut data yang menurut Terdakwa berasal dari I Nyoman Ass atau Winarti, Bambang. SR dan juga Sulastri. Sebagaimana dinyatakan oleh Tergugat, mereka mempunyai kekuasaan untuk mencopot seseorang menjadi pegawai negeridan sebenarnya yang dirujuk oleh Terdakwa tidak memiliki jabatan tersebut. Sebagaimana dinyatakan majelis hakim, kebenaran yang halal ini memang hanya rekayasa atau perkembangan kebohongan dari Tergugat sehingga para pengamat dibujuk dan diberikan sejumlah uang kepada Tergugat.

Menimbang, bahwa berdasarkan hal tersebut, majelis hakim menilai bahwa komponen "Dengan harapan secara melawan hukum membantu diri sendiri atau orang lain dengan menggunakan nama palsu atau penghormatan palsu dengan tipu muslihat atau perkembangan kepalsuan" telah terpenuhi.

Ad. 3. Mendorong orang lain untuk menyerahkan sesuatu kepadanya atau memberikan kewajiban atau potongan piutang;

Bahwa arti pindah di sini adalah untuk mempengaruhi dengan licik sebagai nama palsu atau kondisi palsu, menyesatkan, atau membuat ketidakbenaran, sehinggaseseorang terpengaruh dan setuju untuk melakukan sesuatu, seperti menyerahkanproduk tertentu, membuat kewajiban atau mengabaikan kewajiban.

Menimbang, sementara melihat kenyataan yang terungkap di pendahuluan seperti yang digambarkan dalam percakapan komponen pertama dan kedua, yang menurut Majelis Hakim tidak dapat dipisahkan dan membentuk satu kesatuan dengan komponen ini, telah ditunjukkan bahwa karena kata-kata (rangkaian) kebohongan yang telah dibuktikan dalam pembuktian komponen selanjutnya sebagaimana dimaksud di atas, maka demikian korban bergerak saksi Jumase Bin H.Caring, saksi Sudirman Bin H.Caring, saksi Sumrah Binti H. Sadar dan saksi Saenal Bin Basri menyapa Basri Bin H. Zainuddin untuk menyerahkan berbagai uang kepada pihak berperkara dalam beberapa tahap dengan jumlah keseluruhan Rp. 160.000.000 (seratus enam puluh juta rupiah) diserahkan kepada penggugat.

Mengingat komponen ketiga, sebagaimana ditunjukkan oleh Majelis Hakim, telah dibuktikan secara sah dan 
meyakinkan.

Menimbang, bahwa karena unsur-unsur Surat Dakwaan Penuntut Umum telah dipenuhi, maka dakwaan Penuntut Umum telah dibuktikan secara sah dan meyakinkan oleh undang-undang bahwa Terdakwa telah melakukan tindak pidana yang berlangsung terkendali dan tergantung pada perbuatan pidana berdasarkan Pasal378 KUHP.

Menimbang, karena dakwaan elektif utama Penuntut Umum telah dibuktikan secara sah dan meyakinkan, Majelis tidak akan memikirkan dakwaan elektif kedua.

Menimbang, bahwa dengan terpenuhinya komponen-komponen Pasal 378 KUHP, maka komponen utama "barang siapa" telah terlebih dahulu dipuaskan bahwa Terdakwa adalah pelaku tindak pidana demonstrasi untuk keadaan tersebut.

Menimbang, bahwa dari dakwaan Pasal 378 KUHP yang telah dinyatakan dapat dibuktikan, maka Majelis Hakim selanjutnya akan mempertimbangkan reaksi penggugat terhadap penjelasan di balik pelanggaran Pasal 74 UU No. KUHP mengenai delik aduan dan sedapat mungkin gerutuan, bahwa Pakar Polri mendapat keberatan setelah melampaui sedapat mungkin yang dipersyaratkan oleh Pasal 74 ayat dan (2) KUHP.

Menimbang, bahwa pada umumnya Pasal 74 KUHP merupakan hal yang esensial bagi KUHP Bab VI tentang "Menanamkan dan mencabut keberatan dalam perkara pidana yang harus diajukan atas pengaduan". Sementara delik gerutuan dicirikan sebagai jenis kesalahan tertentu yang harus diajukan atas permintaan atau keluhan individu yang menjadi sasaran terjadinya kriminal. Sedangkan secara terbatas, delik protes dikelompokkan menjadi dua bagian, yaitu delik langsung menggerutu dan delik keberatan relatif. Pasal 378 KUHP tersebut dikecualikan dari kelompok delik langsung menggerutu, namun diingat untuk rumpun delik protes secara keseluruhan berpedoman pada prasyarat bahwa pelakunya adalah kerabat korban dalam perbuatannya.

Menimbang, bahwa selama tidak ada bukti dan kenyataan adanya hubungan kekeluargaan antara yang berperkara sebagai pelaku suatu perbuatan salah dan pemerhati orang yang bersangkutan, maka untuk keadaan ini digunakan Pasal 378 KUHP. KUHP tidak memenuhi model sebagai delik aduan, maka penggunaan Pasal 74 KUHP sebagai alasan yang dikemukakan oleh termohon tidak tepat, maka alasan tersebut dinyatakan gugur.

Menimbang, bahwa dari dakwaan Pasal 378 KUHP yang telah diproklamirkan, maka Majelis Hakim selanjutnya akan mempertimbangkan tanggapan termohon terhadap pelanggaran Pasal 76 KUHP tentang pelarangan mendokumentasikan suatu perkara untuk kedua kalinya dalam suatu demonstrasi/perkara yang telah dipilih oleh pengadilan yang mempunyai kekuatan legitimasi yang sangat kuat, karena subjek dan objek yang sama dan pengadilan yang serupa (Nebis In Idem), hal ini juga diatur dalam Pasal 18 ayat (5) UU No. Pemberantasan perkara ini penting bagi penyidik korban yang telah merinci kejadian serupa kepada penyidik Polri karena adanya pengaturan CPNS tahun 2009 dimana perkara tersebut mempunyai kekuatan legitimasi super tahan lama, bahwa standar yang diterapkan dalam hukum pidana dititikberatkan pada kegiatan, bukan dilihat secara perorangan, bahwa kenyataan dan bukti yang ada sekarang yang dijadikan alasan permintaan penyidik telah $\mathrm{b}$ een diwakili a dipilih oleh pengadilan serupa padatahun 2010.

Menimbang, bahwa Pasal 76 KUHP menyatakan bahwa "(1) Kecuali dalam hal pilihan hakim dalam hal apapun dapat diulang kembali, seseorang tidak dapat didakwa dua kali karena suatu demonstrasi yang dilakukan oleh penguasa yang ditunjuk Indonesia terhadapnya. dengan suatu pilihan akhir.Dalam perasaan pejabat yang ditunjuk Indonesia, termasuk hakim dari pengadilan independen dan standar, di tempat-tempat yang memiliki pengadilan tersebut.(2) Jika kesimpulan resmi datang dari hakim lain, maka, pada saat itu, terhadap orang itu dan sehubungan dengan kesalahan tersebut, tidak ada dakwaan yang dapat diajukan karena:

a. Pilihan sebagai pembenaran dari tuntutan atau pemutusan dari tuntutan;

b. Pilihannya adalah sebagai hukuman dan telah dijalani seluruhnya atau telah dibebaskan atau kedudukannya menjadi batal karena telah lewat.

Menimbang, bahwa tergantung dari alasan penggugat dan penggambaran Pasal 76 KUHP, Majelis Hakim menilai penting untuk terlebih dahulu menggambarkan hubungan antara keadaan umum dengan cara terjadinya tindak pidana yang dituntut dilakukan oleh termohon dalam perkara pokok yang mempunyai kekuatan legitimasi super tahan lama yang hukumannya telah dijalani. oleh termohon sekarang, dengan peristiwa pidana yang didakwakan dalam kasus berikutnya.

Dengan demikian, seperti yang saya lihat, faktor sebenarnya yang dapat membuat penilaian yang kontradiktif pada kasus pungli dalam Putusan Nomor 150/Pid.B/2013/PN.BLK bukanlah penggunaan pasal 378 untuk situasi, tetapi karena penilaian tidak setuju Hakim Anggota II. Untuk situasi ini, melihat Eksepsi hanya sebagai gambaran dalam Perkara Pokok yang berbicara tentang pedoman Pasal 76 KUHP, khususnya tentang aturan (nebis in idem) sehingga menjadi faktor bagi Anggota Hakim. II untuk mengarahkan penilaian yang bertentangan, dengan alasan bahwa sesuai dengan otoritas yang ditunjuk, kebutuhan agregat untuk standar nebis in 
idem untuk situasi ini telah terpenuhi.

\section{SIMPULAN}

Berdasarkan hasil pembahasan tersebut diatas, maka dapat disimpulkan yaitu:

1. Penilaian yang bertentangan merupakan landasan yang melegitimasi pembedaan penilaian hakim (minoritas) atas pilihan pengadilan. Dalam keseluruhan undang-undang ini, penilaian yang bertentangan digunakan dalam hal ada perbedaan penilaian antara otoritas yang ditunjuk dan hakim lain yang pilihannya lebih besar. Perspektif juri yang tidak sama dengan pilihan juga akan dikaitkan dengan pilihan dan menjadi penilaian yang kontradiktif. Sejak lahirnya Undang-Undang Nomor 4 Tahun 2004 perihal Kekuasaan Kehakiman, telah terjadi pertunjukkan di antara individu-individu dari suatu majelishakim dimana apabila dalam rapat musyawarah majelis hakim tidak tercapai kesepakatan, penilaian minoritas memutuskan yang berbeda-beda dari efek samping dari pertemuan pertimbangan para hakim harus diingat untuk bagian pilihan dan struktur pilihan. yang merupakan bagian yang diperlukan dari pilihan.

2. Bahwa faktor yang bisa membuat dissenting opinion perkara penipuan dalam Putusan Nomor 150/Pid.B/2013/PN.BLK adalah bukan terletak pada penerapan pasal 378 dalam perkara tersebut, akan tetapi karena Hakim Anggota II yang dissenting opinion dalam halini melihat Eksepsi juga uraian dalam Pokok Perkara yang membahas mengeni aturan pasal 76 KUHP yaitu mengenai asas (nebis in idem) sehingga menjadi faktor bagi Hakim

Anggota II melakukan dissenting opinion, karena menurut hakim tersebut syarat-syarat kumulatif azas nebis in idem dalam perkara ini telah terpenuhi. Pertimbangan hakim anggota atas perkara penipuan yang menjadi dissenting opinion dalam Putusan Nomor 150/Pid.B/2013/PN.BLK sebagaimana dapat dilihat berdasarkan fakta-fakta persidangan dan bukti yang ada dalam perkara pidana penipuan tersebut yang menjadi pertimbangan hakim anggota sehingga mengakibatkan adanya disseting opinion adalah karenan adanya perbedaan penafsiran azas hukum Nebis in idem dan hak keperdataan para saksi korban.

\section{DAFTAR PUSTAKA}

\section{Buku}

Abdulkadir Muhammad, Hukum dan Penelitian Hukum, Bandung: PT.Citra Aditya Bakti,2004.

Andi Hamzah, Asas-Asas Hukum Pidana, Jakata: Rineka Cipta, 2008 Bagir Manan, Dissenting Opinion Dalam Sistem Peradilan Indonesia,

Jakarta: Varia Peradilan Majalah Hukum, 2006

Bambang Sugono, Metodelogi Penelitian Hukum, Jakarta: Raja Grafindo Persada, 1997 Darmoko Yuti Witanto dan Arya Putra Negara Kutawaringin, Diskresi Hakim Sebuah

Instrumen Menegakkan Keadilan Substantif dalam Perkara - Perkara Pidana,Bandung: Alfabeta, 2013

Dellyana, Shant, Konsep Penegakan Hukum. Yogyakarta: Liberty, 1988 Leden Marpaung, Asas-Teori-Prsktik Pidana,Jakarta: Sinar Grafika, 2009

M. Holyone N Singadimeja, Oci Senjaya, Margo Hadi Pura, 2019, Hukum Pidana Indonesia,

Jakarta Selatan: Adhi Sarana Nusantara

M. Natsir Asnawi, Hermeneutika Putusan Hakim, Yogyakarta: UII Press, 2014

M. Yahya Harahap, Kekuasaan Mahkamah Agung Pemeriksaan Kasasi dan Peninjauan Kembali Perkara Perdata, Jakarta: Sinar Grafika, 2008

Mukti Arto, Praktek Perkara Perdata pada Pengadilan Agama, cet V, Yogyakarta: Pustaka Pelajar,2004

Peter De Cruz, Perbandingan Sistem Hukum Coomon Law, Civil Law dan Socialist Law,Bandung: Nusa Media, 2010

Pontang Moerad B.M, Pembentukan Hukum Melalui Putusan Pengadilan Dalam Perkara Pidana, Bandung: P.T Alumni, 2005

R. Abdoel Djamali, 2010, Pengantar Hukum Indonesia, Jakarta: Rajawali Pres

Roeslan Saleh, Pertanggungjawaban Pidana Dalam Hukum Pidana, Jakarta: Bina Aksara,1983

Soedjono Dirdjosisworo, Hukum Pidana Indonesia dan Gelagat Kriminalitas Masyarakat Pasca Industri, Jakarta: Sinar Grafika, 1991

Sri Sutatiek, Menyoal Akuntabilitas Moral Hakim Pidana Dalam Memeriksa, Mengadili dan Memutus Perkara, Yogyakarta: Aswaja Pressindo, 2013

Sudikno Mertokusumo, Mengenal Hukum, Yogyakarta: Liberty, 2007 Teguh Prasetyo, Hukum pidana, Jakarta: PT. Raja Grafindo Persada, 2015

Wirdjono Prodjodikoro, Tindak-Tindak Pidana Tertentu di Indonesia, Bandung: ReffikaAditama, 2003 
M. Jordy Dwipayana dan Maharani Nurdin, Tinjauan Yuridis Dissenting Opinion terhadap Hakim Anggota Atas Perkara Tindak Pidana Penipuan

\section{Peraturan Perundang-Undangan}

Undang-Undang Dasar Negara Republik Indonesia Tahun 1945

Undang-Undang Nomor 48 Tahun 2009 Tentang Kekuasaan Kehakiman

Kitab Undang-undang Hukum Pidana

Kitab Undang-undang Hukum Acara Pidana

Putusan Nomor: 150/Pid.B/2013/PN.BLK.

\section{Internet}

http://pn-pasangkayu.go.id/index.php/profil/tugas-pokok-dan-fungsi

https://www.hukumonline.com/berita/baca/lt51f1005f68a4c/idissenting-opinion-i-di-mata- mantan-hakim-agung http://www.negarahukum.com/hukum/dissenting-opinion.html 